\title{
The Concept and Importance of Alternative Strategy as Parallel Strategy to be followed in Organizational Decisions to Ensure Success
}

\author{
P. S. Aithal ${ }^{1}$ \& Architha Aithal ${ }^{2}$ \\ ${ }^{1}$ Srinivas Institute of Management Studies, Srinivas University, Mangalore - 575001, INDIA \\ ${ }^{2}$ Third Year Pharma D., Srinivas College of Pharmacy, Valachil, Mangalore - 574143, INDIA \\ E-mail: psaithal@gmail.com; aithalarchithal@gmail.com
}

Type of the Paper: Research Paper.

Type of Review: Peer Reviewed.

Indexed in: OpenAIRE.

DOI: http://doi.org/10.5281/zenodo.1302779.

Google Scholar Citation: $\underline{\text { IJMTS }}$

How to Cite this Paper:

Aithal, P. S.\& Architha Aithal. (2018). The Concept and Importance of Alternative Strategy as Parallel Strategy to be followed in Organizational Decisions to Ensure Success. International Journal of Management, Technology, and Social Sciences (IJMTS),3(2), 1-15 (2581-6012). DOI: http://doi.org/10.5281/zenodo.1302779.

International Journal of Management, Technology, and Social Sciences (IJMTS)

A Refereed International Journal of Srinivas University, India.

(C) With Authors.

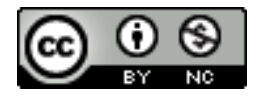

This work is licensed under a Creative Commons Attribution-Non Commercial 4.0 International License subject to proper citation to the publication source of the work.

Disclaimer: The scholarly papers as reviewed and published by the Srinivas Publications (S.P.), India are the views and opinions of their respective authors and are not the views or opinions of the SP. The SP disclaims of any harm or loss caused due to the published content to any party. 


\title{
The Concept and Importance of Alternative Strategy as Parallel Strategy to be followed in Organizational Decisions to Ensure Success
}

\author{
P. S. Aithal ${ }^{1}$ \& Architha Aithal $^{2}$ \\ ${ }^{1}$ Srinivas Institute of Management Studies, Srinivas University, Mangalore - 575001, INDIA \\ ${ }^{2}$ Third Year Pharma D., Srinivas College of Pharmacy, Valachil, Mangalore - 574143, INDIA \\ E-mail:psaithal@gmail.com; aithalarchithal@gmail.com
}

\begin{abstract}
Organizations and individuals usually have well defined objectives at any given point of time and invest their resources systematically to fullfill the objectives by setting their goal and formulating and following a strategy to chase their goal. Various strategies are used to chase the goal in both organizational and individual cases include competitive strategies or red ocean strategies, monopoly or blue ocean strategies, sustainability or green ocean strategies, survival or black ocean strategies, and mixed or white ocean strategies. The complexities of business decisions after globalization of business and technification of business processes, winning or sustaining or even surviving in current business is considered as an intensive challenge for organizations and also to individuals. In such environment called the turbulent business or social environment for organizations and individuals respectively, a new strategy for survival called "Alternative Strategy" is proposed in this paper and the concept of the strategy, its importance in the current business environment for organizational decisions are discussed. The paper also looks into the understanding of the Generic strategies, their applicability and constraints while identifying the importance of alternative strategy. Eight postulates are developed to support the concept of alternative strategy, and an alternative strategy model is suggested using lateral thinking techniques. The model consists of evaluating and comparing the alternative strategy with primal strategy using ABCD analysis framework. Such model of alternative strategy can be used at operational level, tactical level, and strategic level of any organization to realize its objectives.
\end{abstract}

Keywords:Organizational strategy, Goal reaching, Competitive strategy, Technification of business processes, Monopoly, Sustainable strategy, Survival strategy, Alternative strategy, Aithal Postulates on Alternative Strategies.

\section{INTRODUCTION :}

Strategy is a systematic plan of action to ensure success or to reach desired future state. Strategy is mainly about a set of options and choice of a course of action among them to achieve the expected outcome. Strategy is an important action to achieve an individual goal, to achieve organizational objectives and solve major problems, to fulfil government objectives, and to manage challenges of even military systems. Organizations and individuals usually have well defined objectives at any given point of time and invest their resources systematically to fullfill the objectives by setting their goal and formulating and following a strategy to chase their goal.

In general, strategy is considered as a very important tool to resolve certain aspects of the various frame of references as listed in Table 1. Various generic strategies are used and modelled in strategic management research especially in business dealings both in organizational and individual cases include competitive strategies or red ocean strategies systematically organized by 
M.E. Porter [1], monopoly or blue ocean strategies systematically organized by [2], sustainability or green ocean strategies systematically organized by [3], survival or black ocean strategies systematically organized by Aithal P. S. [4-6], and mixed or white ocean strategies systematically organized and published by Aithal P. S. [7].

As per another classification, there are three basic kinds of business strategies which include general strategy, corporate strategy, and competitive strategy. Further, strategy models are also classified into three types as linear strategy, adaptive strategy, and interpretive strategy. Linear strategy focuses on planning such that goals, and the means of achieving them, are the results of strategic management [8].
In linear strategy, leaders of the organization plan how they will deal with competitors to achieve their organization's goals. Adaptive strategy focus on the development of a viable match between the opportunities and the risks present in the external environment and the organization's capabilities and resources for exploiting these opportunities [9]. Adaptive strategy focuses on the organization and its internal change, proactively or reactively, to maintain alignment with consumer preferences. Interpretive strategy deals with organizational leaders convey instructions that are intended to motivate stakeholder in ways that improves the performance of the organization [10].

Table 1 : Use of strategy in different Frame of references

\begin{tabular}{|c|c|c|c|}
\hline S. No. & Frame of Reference & Tool & Context of Use \\
\hline 1 & Concept & \multirow{14}{*}{ Strategy } & To explain a concept in understandable manner \\
\hline 2 & System & & To improve the system performance \\
\hline 3 & Idea & & To implement an Idea \\
\hline 4 & Issue & & To identify and resolve an issue \\
\hline 5 & Problem & & To solve a problem optimally \\
\hline 6 & Objective & & To fulfil the objectives in minimum time \\
\hline 7 & Responsibility & & To fulfil your responsibility \\
\hline 8 & Model & & To understand and implement a model \\
\hline 9 & Technology & & To develop and adopt a technology \\
\hline 10 & Science & & To prove an issue or event scientifically \\
\hline 11 & Game & & To maximize the gain or minimize loss \\
\hline 12 & Competition & & To win in a competition \\
\hline 13 & Business & & To start and expand business \\
\hline 14 & People & & To manage and satisfy people \\
\hline
\end{tabular}


International Journal of Management, Technology, and Social

\begin{tabular}{|l|l|l|l|}
\hline 15 & Resources & & To utilise resources optimally \\
& Development & & To reach the future desired state \\
\hline
\end{tabular}

\section{OBJECTIVES OF THE RESEARCH :}

The objective of this paper is to systematically analyse the importance of keeping an alternative strategy along with every generic strategy or specific strategies to have a substitute to ensure success. Specifically, it includes:

(1) Introducing a new type of strategy as a systematic strategy as an alternative for the generic strategies to overcome the challenges and constraints of generic strategies.

(2) Defining the alternating strategy as a new effective strategy for solving such problems by developing suitable postulates.

(3) Reviewing the related research to know where and in which subjects people frequently used such alternative strategies.

(4) Understanding Generic strategies, their applicability, and constraints.

(5) Developing postulates to support alternative strategy.

(6) Alternative Strategy Model.

(7) Possibility of using the alternative strategy in operational level, tactical level, and strategic level of business organizations.

\section{RELATED RESEARCH ON} ALTERNATIVE STRATEGIES :

Even though the alternative strategy is not developed systematically as a strategy in the history of strategic management subject, many researchers used it in many areas to solve their problems when normal procedures/methods are prohibitively challenging. Table 2 contains some of such alternative strategies used in various areas to tackle the problems. Many subjects and areas used alternative strategies include Biology, Genetics, Management, economics, social sciences, Agricultural science, Water technology, Energy, Sociology, education, Political science, Information science, Medical sciences, Nanotechnology, Electronics, statistics and Mathematics, Pharmacy, etc. Many types of research in cancer treatments also use various alternative strategies. But in this paper, we have proposed systematic thinking on alternative strategy and its usage if the prevailing strategy fails. Keeping an alternative strategy in any business decision is important now a day due to the need of sustainability in future competitions.

Table 2 : Some of theAlternative strategies used in various areas to tackle the problems

\begin{tabular}{|c|c|c|c|c|c|}
\hline S. No & $\begin{array}{c}\text { Alternative Strategy } \\
\text { discussed }\end{array}$ & Subject/Area & Year & Authors & Reference \\
\hline 1 & $\begin{array}{l}\text { Development of Welfare } \\
\text { state }\end{array}$ & Economics & 1992 & $\begin{array}{l}\text { Whitfield, D. } \\
\text { (1992). }\end{array}$ & [11] \\
\hline 2 & Doing Research & $\begin{array}{l}\text { Management } \quad \& \\
\text { Social science }\end{array}$ & 1988 & $\begin{array}{l}\text { Reisman, } \quad \text { A. } \\
\text { (1988). }\end{array}$ & {$[12]$} \\
\hline 3 & Animal reproduction & Genetics & 1983 & $\begin{array}{l}\text { Dunbar, R. I. M. } \\
\text { (1983). }\end{array}$ & [13] \\
\hline 4 & $\begin{array}{l}\text { Product differentiation and } \\
\text { market segmentation }\end{array}$ & Marketing & 1956 & $\begin{array}{lll}\begin{array}{l}\text { Smith, } \\
\text { (1956). }\end{array} & \text { W. } & \text { R. } \\
\end{array}$ & {$[14]$} \\
\hline
\end{tabular}


International Journal of Management, Technology, and Social

\begin{tabular}{|c|c|c|c|c|c|}
\hline 5 & $\begin{array}{l}\text { Resolving cross-cultural } \\
\text { ethical conflict }\end{array}$ & Business Ethics & 1994 & $\begin{array}{l}\text { Kohls, J., \& } \\
\text { Buller, P. (1994). }\end{array}$ & [15] \\
\hline 6 & Weed control & $\begin{array}{l}\text { Pest control in } \\
\text { Agricultural science }\end{array}$ & 1990 & $\begin{array}{l}\text { Altman, J. Et al. } \\
\text { (1990). }\end{array}$ & {$[16]$} \\
\hline 7 & $\begin{array}{l}\text { Organizational Design of } \\
\text { Schools }\end{array}$ & Education & 1990 & Rowan, B. (1990). & {$[17]$} \\
\hline 8 & Paths to scaling-up: & $\begin{array}{l}\text { Non-Governmental } \\
\text { Organizational } \\
\text { strategy }\end{array}$ & 1996 & $\begin{array}{l}\text { Uvin, P., \& Miller, } \\
\text { D. (1996). }\end{array}$ & [18] \\
\hline 9 & Drug development & Pharmaceutics & 1999 & \begin{tabular}{ll|} 
Kuhlmann, & J. \\
(1999). &
\end{tabular} & [19] \\
\hline 10 & Participatory research & Sociology & 1996 & $\begin{array}{lll}\begin{array}{l}\text { Cancian, } \\
\text { (1996). }\end{array} & \text { F. } & \text { M. } \\
\end{array}$ & [20] \\
\hline 11 & $\begin{array}{l}\text { Tackling the soil salinity } \\
\text { problem }\end{array}$ & Agricultural science & 2,000 & \begin{tabular}{lll|} 
Qureshi, & R. & H. \\
(1993). & & \\
\end{tabular} & {$[21]$} \\
\hline 12 & $\begin{array}{l}\text { Selecting population } \\
\text { controls }\end{array}$ & Epidemiology & 2,000 & $\begin{array}{l}\text { Funkhouser, et al. } \\
\text { (2000). }\end{array}$ & {$[22]$} \\
\hline 13 & $\begin{array}{l}\text { Fulfilling stringent effluent } \\
\text { guidelines }\end{array}$ & $\begin{array}{l}\text { Water Science and } \\
\text { Technology }\end{array}$ & 1994 & $\begin{array}{ll}\text { Eckenfelder, } & \text { W. } \\
\text { W. (1994). } & \end{array}$ & {$[23]$} \\
\hline 14 & To manage cancer & Medicine & 1998 & $\begin{array}{l}\text { Foster Jr, R. S., et } \\
\text { al. (1998). }\end{array}$ & {$[24]$} \\
\hline 15 & $\begin{array}{l}\text { Testing of } \text { Integrated } \\
\text { Circuits }\end{array}$ & Electronics & 2007 & $\begin{array}{l}\text { Chien, C. F., et al. } \\
\text { (2007). }\end{array}$ & {$[25]$} \\
\hline 16 & $\begin{array}{l}\text { Wastewater recycling and } \\
\text { reuse }\end{array}$ & Water technology & 2003 & $\begin{array}{l}\text { Ganoulis, } \\
\text { (2003). }\end{array}$ & {$[26]$} \\
\hline 17 & $\begin{array}{l}\text { Digitizing the qualitative } \\
\text { research process }\end{array}$ & Information Science & 2002 & Brown, D. (2002), & [27] \\
\hline 18 & $\begin{array}{l}\text { Moors' model in randomized } \\
\text { response sampling }\end{array}$ & Statistical methods & 2000 & $\begin{array}{l}\text { Singh, S., at al. } \\
(2000)\end{array}$ & [28] \\
\hline 19 & Cost-effectiveness analysis & Vaccination & 2008 & \begin{tabular}{lll|} 
Smith, & K. & J., \\
$(2008)$ & & \\
\end{tabular} & [29] \\
\hline 20 & Assuring blood safety & Biology & 2010 & $\begin{array}{llr}\text { Epstein, } & \text { J. } & \text { S. } \\
\text { (2010). } & & \end{array}$ & [30] \\
\hline
\end{tabular}


International Journal of Management, Technology, and Social

\begin{tabular}{|c|c|c|c|c|c|}
\hline 21 & $\begin{array}{l}\text { Improved Note-taking with } \\
\text { computers }\end{array}$ & Automation & 2013 & $\begin{array}{l}\text { Bui, D. C. Et al } \\
\text { (2013) }\end{array}$ & [31] \\
\hline 22 & $\begin{array}{l}\text { Global politics of } \\
\text { development }\end{array}$ & Political Science & 2012 & $\begin{array}{l}\text { Vom Hau, M., } \\
(2012)\end{array}$ & [32] \\
\hline 23 & $\begin{array}{lll}\text { Spatial reasoning with } \\
\text { diagrams }\end{array}$ & Mathematics & 2010 & $\begin{array}{l}\text { Stieff, M., et al. } \\
\text { (2010) }\end{array}$ & [33] \\
\hline 24 & To reduce tax evasion & Income tax & 2011 & Alm, J. (2011). & [34] \\
\hline 25 & $\begin{array}{l}\text { Diversification vs. } \\
\text { specialization }\end{array}$ & Economics & 2012 & $\begin{array}{l}\text { Kaulich, } \\
\text { Florian (2012) }\end{array}$ & [35] \\
\hline 26 & $\begin{array}{l}\text { Safety assessment of } \\
\text { engineered nanomaterials }\end{array}$ & Nano medicine & 2013 & Nel, A. E. (2013). & [36] \\
\hline 27 & Task Shifting & Healthcare & 2017 & $\begin{array}{l}\text { Architha Aithal et } \\
\text { al (2017). }\end{array}$ & [37-39] \\
\hline
\end{tabular}

\section{IMPORTANCE OF STRATEGIC MANAGEMENT AND VARIOUS STRATEGIES ADOPTED :}

Strategy is considered as an important task in organizational and individual effort of achieving the long term goal. A systematic strategy development and implementation ensure to winning the challenge and in such case, proper management of planned strategy by means of making appropriate decisions plays an important role. Table 3 highlights some of the organizational strategic levels and various strategies adopted by managers while making decisions towards solving their problems or identifying further challenges.

Table 3 : Organizational Strategic Levels and various strategies adopted

\begin{tabular}{|l|l|l|}
\hline S. No. & Organizational Strategic Levels & Strategies adopted \\
\hline 1 & Operational/ Functional level & $\begin{array}{l}\text { Functional level strategies like efficient production, } \\
\text { Effective marketing, finance \& accounting, Human } \\
\text { resource management strategies etc. }\end{array}$ \\
\hline 2 & Business level & $\begin{array}{l}\text { Competitive strategies, Monopoly strategy, } \\
\text { Sustainability strategy, Survival strategy etc. }\end{array}$ \\
\hline 3 & Corporate level & $\begin{array}{l}\text { What industry, What business, What jurisdiction, } \\
\text { What team etc. }\end{array}$ \\
\hline
\end{tabular}

5. GENERIC STRATEGIES AND THEIR APPLICABILITY :

Michael Porter in 1985 developed a generic strategy framework [40]. This framework comprises of two alternative strategies for competitive advantage. They are Product/Service differentiation, and/or (2) Low cost leadership. Both have the scope of narrow and broad focus. Here product/service 
differentiation strategy can be also considered as a form of blue ocean strategy and leads to monopoly. Similarly, the low cost leadership strategy can be also considered as a form of red ocean strategy and leads to competition. As per Porter, these generic strategies are also alternative strategies to each other. Here, an organization can choose either low cost leadership strategy or differentiation strategy as two faces of a single coin. These strategies are more useful at the business level and widely applicable to all business organizations of any size and of any industry. Generally, cost leadership can be achieved by economy of scale through automated mass production/service using latest technologies and selling to global customers whereas product/service differentiation can be achieved by creating higher value than those offered by competitors. But in many cases, it is proved that the generic strategies failed to provide a competitive advantage to the firms. In such cases, it is suggested to use mixed strategy [7] for ensuring success. The concept of alternate strategy allows organizations to use other strategies in different circumstances including diversifying product/services, globalization, acquisition, joint venture, liquidation, and retrenching. Thus due to internal and external environmental conditions, an organization should identify a substitute strategy called alternative strategy if the prime strategy fails to yield the expected result.

\section{ALTERNATIVE BUSINESS ISSUES :}

Alternative concepts, systems, models, solutions, strategies are not new in the history. As mentioned in Table 2, various alternative strategic models are being used in many areas since a long time. In business management also the concept of alternatives issues are considered by many people systematically. Some of the Alternative Business Issues are:

\section{(1) Alternative Production:}

It encompasses on alternative ways of producingproposed components / products by utilizing less resources, less time consumption, less wastage and less by-products with the intention to improve the quality and reduce cost [41].

\section{(2) Alternative Marketing:}

It deals with finding a new way of doing marketing to reach the information about the products or services ubiquitously anywhere in the world without increased cost like web marketing [42].

\section{(3) Alternative Strategy:}

This is the topic of this paper and deals with a parallel strategy to competitive or generic strategies in order to ensure success in the job or work of individuals, groups, or organizations without using additional resources. The Concept and Importance of Alternative Strategy made it as a new strategy to be followed in Operational, Business, and Corporate Decisions to ensure Success in intended work.

\section{(4) Alternative Finance:}

The definition of alternative finance includes an instrument, channel, or system of finance which shows the characteristics different than the regulated banking system. Alternative finance may use various technological innovations, like digital currencies, disintermediated business models, online distribution and lending mechanisms to provide alternative ways for traditional finance. The alternative finance has characteristics like transparency, speed, and convenience, and has changed the way people and institutions do businesses and performs financial transactions [43].

\section{Alternative Strategy as Real/Augmented Alternative :}

Generic strategy is a straightforward strategy planned and developed to solve the problem. However, alternative strategy can be a real strategy or an augmented strategy to solve problem with some additional advantages and benefits. These advantages and benefits may be low cost and hence less investment; or minimum processes and hence less time consumption, or improved quality and hence enhanced demand, or wide reachability and hence increased sales, use of technology and hence decreased wastage respectively as given in Table 4 . 
Table 4 : Advantages and benefits of Alternative strategies :

\begin{tabular}{|l|l|l|}
\hline $\begin{array}{l}\text { S. } \\
\text { No. }\end{array}$ & Advantages of Alternative Strategy & Benefits of Alternative Strategy \\
\hline 1 & Low cost & Less investment \\
\hline 2 & Reduced processes & Less time consumption \\
\hline 3 & Improved quality & Enhanced demand \\
\hline 4 & Wide reachability & Increased sales \\
\hline 5 & Technologies based automation & Decreased wastage \\
\hline 6 & Easy to perform & Enhanced performance \\
\hline 7 & Needs detailed study of the problem & Enhanced understanding of the problem \\
\hline
\end{tabular}

\section{Aithal Postulates on Alternative Strategy:}

Alternative strategy is parallel strategy can be also called the dual strategy of the primal, to be used when the primal strategy is considered to be costly, or time consuming, or leads to low quality solution, or easy to perform, or make use of automation to reduce wastage in business processes. The following eight postulates called "Aithal Postulates" are applicable while developing alternative strategy for any primal strategy:

(1) Alternative concept is based on duality principle of nature :

Nature likes duality. In the nature, light shows duality with wave properties and particle properties, every matter/material also shows dual nature as particle nature and wave nature. Similarly in business optimization, every maximization problem has an associated minimization problem as its dual and vice-versa. Hence in decision science, every primal strategy should have an associated dual strategy called Alternative strategy. Alternative strategy can be used equally as parallel strategy which may lead to either maximizing or minimizing the advantages and the benefits.

(2) Technification of processes in the organization supports Alternative strategy:

The complexities of business decisions after globalization of business and technification (automation of processes using technology) of business processes by means of technology based automation leads to decrease in cost, improved quality, enhanced efficiency, reduction in performance time, and minimization of wastage. Technification based strategy is the only solution for winning or sustaining or even surviving in current business and other organizations challenges. The proposed alternative strategy focus on possible technification of business processes.

(3) Alternative strategy is based on Customization of Business services:

Customization of business services are present requirement. Customization in business services consists of cutting-edge management methods, processes and tools that give organizations the capability to produce customized, affordable, high-quality goods and services, at optimum time and cost. Optimized customization of the characteristics of business services at a given location, given time, and specified amount of time gives rise to the requirement of alternative strategy. As customers and their needs grow increasingly diverse, customization approach has its own difficulties in the way to add unnecessary cost and complexity to business operations. In this regard, alternative approaches on designing or redesigning a product, process, or business service, leads to possible insights into how to 
serve their customers best.

(4) Alternative strategy should focus on Delighting the customers:

The implementation of optimized customization in business services leads to customer delight. Alternative strategies of a planned strategy should focus on customer delight so that the business model can expect long term sustainability and the organization can get the benefit of enhanced profit. Delighting the customers is a strategy to transform an organization into customer driven organization. Alternative strategy should focus on adding key elements like delivering the promise, providing a personal touch, going the extra mile, and resolving customers problems.

(5) Alternative strategies should become active when Convectional (primal) Strategies fails in reaching optimum solution:

The organizational internal and environmental factors affect the implementation of planned primal strategy. In such cases the decision makers in the organization should think on alternative strategy which has both advantages and benefits in reaching the optimum solution.

(6) Alternative strategies focus on organizational sustainability:

Organizational sustainability depends on internal resources and capabilities, the business model, the nature and relevance of technification, competitiveness and innovation ability, legitimacy, future-look on opportunities and preparedness. The alternative strategy may focus on these aspects while re-look into the alternatives for sustainability.

(7) Alternative strategies focus on increasing the overall performance :

Increasing overall performance of an organization based on re-looking into its strategy is essential in present business scenarios and environment. Various theories and methods helps such improvements in overall performance of the organizational productivity either by increasing their efficiency or by effectiveness or both. In this regard, many theories of $20^{\text {th }}$ century including Theory $\mathrm{X}$, Theory $\mathrm{Y}$, and Theory $\mathrm{Z}$ will help to develop primal strategies [44] and to counter or with new outlook, $21^{\text {st }}$ century organizational performance theories including recently developed Theory A (Theory of Accountability) helps the decision makers to develop alternative strategy for increasing overall performance [45-49].

(8) Alternative strategy need not be new strategy:

A well-known generic strategy can be alternative strategy for a given strategy under consideration. For example, in table 5, some of the generic strategies and possible alternative strategies are listed. Depending on the place, time, and situation, some of the already identified strategies can be used as alternative strategy for a primal strategy. Based on evaluation of existing strategies using ABCD framework of analysis [50-51] one can find an alternative strategy for the primal strategy.

\section{Alternative Strategy Model :}

Alternative Strategy model is based on Aithal Postulates. The model consists of evaluation of primal strategy for its desired output/performance and if not satisfied, developing an alternative strategy in any stage like at the beginning or at any stage during the primal strategy implementation process. The model uses advantages and benefits analysis in comparison with constraints and disadvantages analysis in ABCD analysis framework [50-51]. The model consists of four stages : (1) Developing alternating strategy using some lateral thinking techniques, (2) Evaluating the alternative strategy using suitable analysis framework, (3) Comparing alternating strategy with primal strategy using comparative analysis. Lateral thinking techniques like six thinking hats [52-55] can be used in this regard. (4) Choosing the best strategy out of primal and alternative for implementation in the organization. ABCD framework is recently developed system, concept, and strategy analysis framework, useful for analysing and comparing strategies based on four constructs called advantages, benefits, constraints, and disadvantages. Many research papers used this analysis method for studying affecting factors and critical constituent elements based on identifying various issues related to the stakeholders [56-70]. 


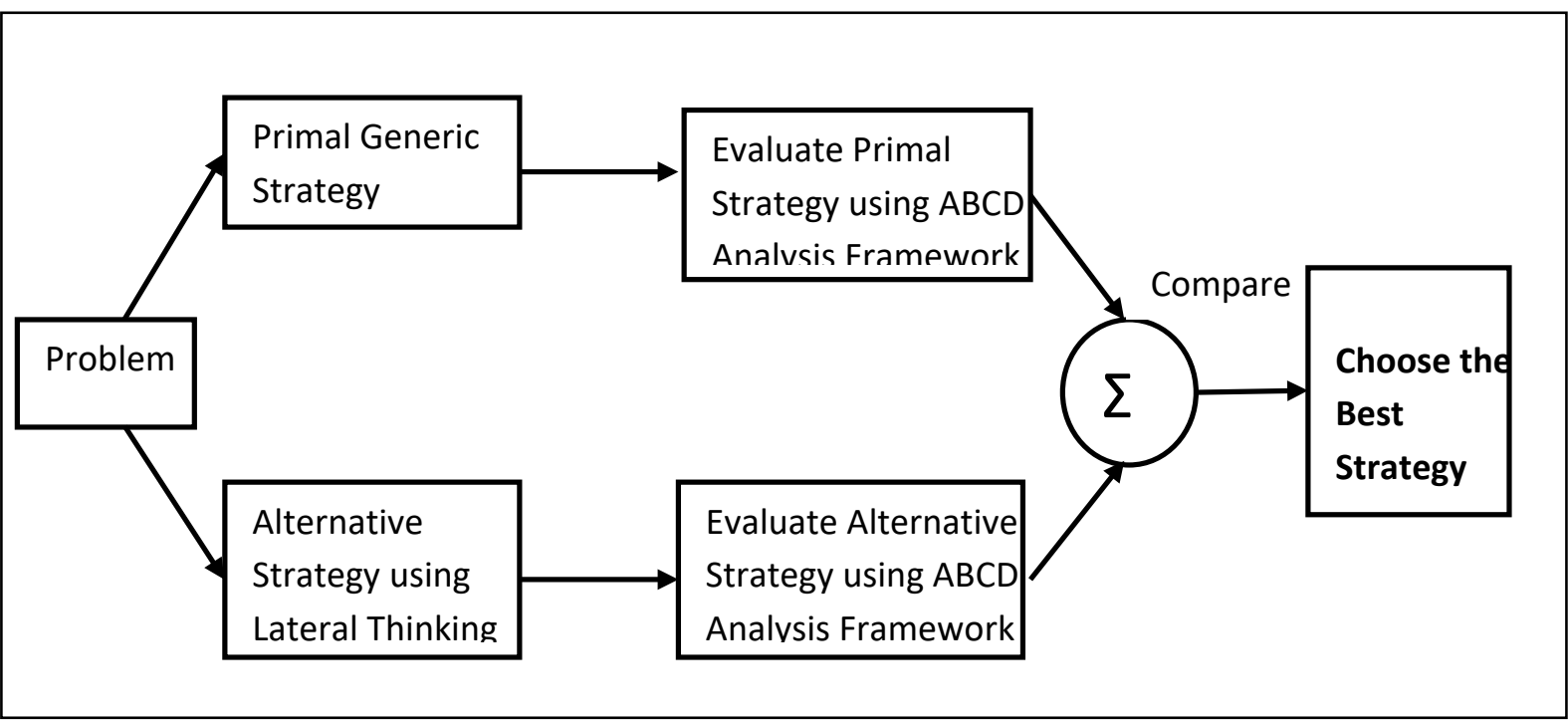

Fig. 1 : Alternative strategy model based on lateral thinking \& ABCD analysis

The detailed study on developing, evaluating, and implementing alternative strategies in various organizations for the different industries is in progress and will be published soon.

\section{Alternative Strategy as Alternative for Generic Strategies :}

Alternative strategy is useful when the primal strategy is already developed for a problem and the decision maker may feel or realize that a new or improved strategy will improve the solution due to the fact that optimum solution changes with changes in internal and external aspects in the organization. Such changes in internal and environmental factors allow the decision maker to develop alternative strategy to further improve the solution. Both primal strategy and alternative strategy are developed to find optimum solution i.e., have same final objective. But the amount of resources they consume including time may vary so that one strategy gets importance over other or vice-versa. The organization may plan alternative strategy at any stage if it feels so during its way of solving problems to realize its goal. Table 5 lists some of the generic strategies the organizations follow and their possible alternative strategies to be considered.

Table 5 : List of Generic strategies and possible alternative strategies

\begin{tabular}{|l|l|l|}
\hline S. No. & Generic Strategies & Alternative Strategies \\
\hline 1 & Low cost leadership & Differentiation \\
\hline 2 & Product/Service differentiation & Low cost leadership \\
\hline 3 & Diversifying & Liquidation, Globalization \\
\hline 4 & Globalization & Retrenching, Acquisition \\
\hline 5 & Acquisition & Joint venture, Globalization \\
\hline 6 & Joint venture & Acquisition, Globalization \\
\hline
\end{tabular}


International Journal of Management, Technology, and Social

\begin{tabular}{|l|l|l|}
\hline 7 & Liquidation & Diversifying, Retrenching \\
\hline 8 & Retrenching & Globalization, Diversifying \\
\hline
\end{tabular}

Apart from above strategies mentioned in table 5, a decision maker may develop a new strategy as an alternative strategy which may be white ocean strategy consisting of the mixture of all generic strategies including red ocean strategy, blue ocean strategy, green ocean strategy, and even black ocean strategy.

\section{Conclusion :}

The concept of alternative strategy is systematically analysed by considering the importance of keeping an alternative strategy along with every generic strategy or specific strategies to have a substitute to ensure success. Based on identifying various alternative strategies used in different subject areas the importance of alternative strategy is evaluated. Using our definition of alternative strategy as a new effective strategy for solving such problems, suitable postulates are developed. The paper also focussed on the understanding the Generic strategies, their applicability, and constraints while identifying the importance of alternative strategy. Based on importance of the alternative strategy, eight postulates are developed to support the concept and discussed. The alternative strategy model is suggested using lateral thinking techniques and evaluating and comparing it with a primal strategy using ABCD analysis framework. Such model of alternative strategy can be used at operational level, tactical level, and strategic level of any type of organization to realize its objectives.

\section{REFERENCES :}

[1] Porter, M. E. (1997). Competitive strategy. Measuring Business Excellence, 1(2), 1217.

[2] Kim, W. C., \& Mauborgne, R. (2005). Blue ocean strategy. California management review, 47(3), 105-121.

[3] Hou, Shengtian (2007) Green ocean strategy: Obtaining sustainable competitive advantage, Beijing: Tsinghua University
Press, pp. 183-197.

[4] Aithal P. S., Suresh Kumar P. M., (2015). Black Ocean Strategy - A Probe into a New type of Strategy used for Organizational Success. GE International Journal of Management Research, 3(8), 45 - 65. DOI : http://doi.org/10.5281/zenodo.163423.

[5] Aithal, P. S., Shailashree V. T., \& P.M. Suresh Kumar, (2015). Application of ABCD Analysis Model for Black Ocean Strategy. International Journal of Applied Research (IJAR), 1(10), 331 - 337, DOI : http://doi.org/10.5281/zenodo.163424.

[6] Aithal, P. S. \& Acharya, R. K. (2016). Strategic Management Models \& Indian Epics, International Journal of Management Sciences and Business Research (IJMSBR), 5(4), 180-188. DOI :http://doi.org/10.5281/zenodo.161093.

[7] Aithal, P. S. (2016). The concept of Ideal Strategy \& its realization using White Ocean Mixed Strategy, International Journal of Management Sciences and Business Research (IJMSBR), 5(4), 171179. DOI :http://doi.org/10.5281/zenodo.161108.

[8] Chaffee, E. E. (1985). Three models of strategy. Academy of management review, 10(1), 89-98.

[9] Hofer, C. W. (1973, August). Some preliminary research on patterns of strategic behavior. Academy of Management Proceedings, 1973(1), 46-54).

[10] Weick, K. E., \& Daft, R. L. (1983). The effectiveness of interpretation systems. In Organizational effectiveness (pp. 71-93). Elsevier.

[11] Whitfield, D. (1992). Welfare State: Privatisation, Deregulation, Commercialisation of the Private Sector: Alternative Strategies for the 1990's. 
PlutoPress (UK).

[12] Reisman, A. (1988). On alternative strategies for doing research in the management and social sciences. IEEE Transactions on Engineering Management, 35(4), 215-220.

[13] Dunbar, R. I. M. (1983). Life history tactics and alternative strategies of reproduction. Mate Choice, 423-433.

[14] Smith, W. R. (1956). Product differentiation and market segmentation as alternative marketing strategies. Journal of marketing, 21(1), 3-8.

[15] Kohls, J., \& Buller, P. (1994). Resolving cross-cultural ethical conflict: Exploring alternative strategies. Journal of Business Ethics, 13(1), 31-38.

[16]Altman, J., Neate, S., \& Rovira, A. D. (1990). Herbicide-pathogen interactions and mycoherbicides as alternative strategies for weed control.

[17]Rowan, B. (1990). Chapter 7: Commitment and Control: Alternative Strategies for the Organizational Design of Schools. Review of research in education, 16(1), 353-389.

[18] Uvin, P., \& Miller, D. (1996). Paths to scaling-up: alternative strategies for local nongovernmental organizations. Human Organization, 55(3), 344-354.

[19] Kuhlmann, J. (1999). Alternative strategies in drug development: clinical pharmacological aspects. International journal of clinical pharmacology and therapeutics, 37(12), 575-583.

[20] Cancian, F. M. (1996). Participatory research and alternative strategies for activist sociology. Feminism and social change: Bridging theory and practice, 187205.

[21] Qureshi, R. H. (1993). Alternative strategies for tackling the soil salinity problem. Dept. of Soil Science, University of Agriculture, Faisalabad, 9.

[22] Funkhouser, E., Macaluso, M., \& Wang, X.
(2000). Alternative strategies for selecting population controls: comparison of random digit dialing and targeted telephone calls. Annals of epidemiology, 10(1), 59-67.

[23] Eckenfelder, W. W. (1994). Alternative strategies for meeting stringent effluent guidelines. Water Science and Technology, 29(8), 1-7.

[24] Foster Jr, R. S., \& Wood, W. C. (1998). Alternative strategies in the management of primary breast cancer. Archives of Surgery, 133(11), 1182-1186.

[25] Chien, C. F., Wang, H. J., \& Wang, M. (2007). A UNISON framework for analyzing alternative strategies of IC final testing for enhancing overall operational effectiveness. International Journal of Production Economics, 107(1), 20-30.

[26] Ganoulis, J. (2003). Evaluating alternative strategies for wastewater recycling and reuse in the Mediterranean area. Water Science and Technology: Water Supply, 3(4), 11-19.

[27] Brown, D. (2002, May). Going digital and staying qualitative: Some alternative strategies for digitizing the qualitative research process. In Forum Qualitative Sozialforschung/Forum: Qualitative Social Research (Vol. 3, No. 2).

[28] Singh, S., Singh, R., \& Mangat, N. S. (2000). Some alternative strategies to Moors' model in randomized response sampling. Journal of Statistical Planning and inference, 83(1), 243-255.

[29] Smith, K. J., Zimmerman, R. K., Lin, C. J., Nowalk, M. P., Ko, F. S., McEllistrem, M. C., \& Roberts, M. S. (2008). Alternative strategies for adult pneumococcal polysaccharide vaccination: a costeffectiveness analysis. Vaccine, 26(11), 1420-1431.

[30] Epstein, J. S. (2010). Alternative strategies in assuring blood safety: An overview. Biologicals, 38(1), 31-35.

[31] Bui, D. C., Myerson, J., \& Hale, S. 
(2013).Note-taking with computers: Exploring alternative strategies for improved recall. Journal of Educational Psychology, 105(2), 299.

[32] Vom Hau, M., Scott, J., \& Hulme, D. (2012). Beyond the BRICs: Alternative strategies of influence in the global politics of development.

[33] Stieff, M., Hegarty, M., \& Dixon, B. (2010). Alternative strategies for spatial reasoning with diagrams. In Diagrammatic representation and inference (pp. 115-127). Springer, Berlin, Heidelberg.

[34] Alm, J. (2011). Designing alternative strategies to reduce tax evasion. Tax evasion and the shadow economy, 13-32.

[35] Kaulich, Florian (2012) Diversification vs. specialization as alternative strategies for economic development: Can we settle a debate by looking at the empirical evidence? United Nations Industrial Development Organization (UNIDO), Vienna. http://epub.wu.ac.at/5232/1/WP032012_Ebo ok.pdf

[36] Nel, A. E. (2013). Implementation of alternative test strategies for the safety assessment of engineered nanomaterials. Journal of internal medicine, 274(6), 561-577.

[37] Architha Aithal, \& Aithal, P. S. (2017). Task Shifting - An Alternative Survival Strategy for Health-care Organizations. International Journal of Scientific Research and Modern Education (IJSRME), 2(2), 3448. DOI :http://doi.org/10.5281/zenodo.995627.

[38] Architha Aithal, \& Ateendra Jha (March 2017). Task Shifting : A Need for Current Health Care System. Saudi Journal of Medicine and Pharmaceutics, 3(3), 1-12. DOI:

http://doi.org/10.21276/sjmps.2017.3.3.1.

[39] Architha Aithal, \& Ateendra Jha (2017). An Empirical study on the importance of Task Shifting in current Health Care System. International Journal of
Management, Technology and Social Sciences (IJMTS), Srinivas Publishers, 1(1), 14-25, DOI: http://doi.org/10.5281/zenodo.438334.

[40] Porter, M. E. (1985). Technology and competitive advantage. Journal of business strategy, 5(3), 60-78.

[41] Bravo-Ureta, B. E., \& Rieger, L. (1990). Alternative production frontier methodologies and dairy farm efficiency. Journal of agricultural Economics, 41(2), 215-226.

[42] Zinkhan, G. M., \& Hirschheim, R. (1992). Truth in marketing theory and research: an alternative perspective. The Journal of Marketing, 80-88.

[43] Baeck, P., Collins, L., \& Zhang, B. (2014). Understanding alternative finance. The UK alternative finance industry report.http://www.sbs.ox.ac.uk/sites/default/ files/Entrepreneurship_ Centre/Docs/OxEPR2/nesta-understaningalternative-finance.pdf.

[44] McGregor, D. M. (1960). The human side of enterprise. New York: McGraw-Hill.

[45] Aithal, P. S. and Suresh Kumar, P. M. (2016). Organizational Behaviour in $21^{\text {st }}$ Century - Theory A for Managing People for Performance. IOSR Journal of Business and Management (IOSR-JBM), 18(7), 126134. DOI: http://doi.org/10.9790/487X180704126134.

[46] Aithal, P. S. \& Suresh Kumar, P. M. (2016). Theory A for Optimizing Human Productivity, IRA-International Journal of Management \& Social Sciences, 4(3), 526535. DOI : http://dx.doi.org/10.2101 3/jmss.v4.n3.p2. and DOI : http://doi.or g/10.5281/zenodo.158959.

[47] Aithal, P. S. \& Suresh Kumar, P. M. (2016). CCE Approach through ABCD Analysis of 'Theory A' on Organizational Performance. International Journal of Current Research and Modern Education (IJCRME), 1(2), 169-185.

DOI: http://dx.doi.org/10.5281/zenodo.1647 
$\underline{04}$.

[48] Aithal, P. S., \& Suresh Kumar P. M. (2017). Integrating Theory A and Six Thinking Hats for Improved Organizational Performance. International Journal of Applied Engineering and Management Letters (IJAEML), 1(2), 66-77. DOI: http://dx.doi.org/10.5281/zenodo.1045417.

[49] Aithal, P. S. \& Suresh Kumar, P. M. (2016). Comparative Analysis of Theory X, Theory Y, Theory Z, and Theory A for Managing People and Performance. International Journal of Scientific Research and Modern Education (IJSRME), 1(1), 803-812. DOI: http://doi.org/10.5281/zenodo.154600.

[50] Aithal, P. S., V.T. Shailashree, \& Suresh Kumar, P. M. (April 2015). A New ABCD Technique to Analyze Business Models \& Concepts. International Journal of Management, IT and Engineering (IJMIE), 5(4), 409 - 423. DOI : http://doi.org/10.5281/zenodo.61652.

[51] Aithal, P. S. (2016). Study on ABCD Analysis Technique for Business Models, Business strategies, Operating Concepts \& Business Systems. International Journal in Management and Social Science, 4(1), 98115.

DOI

http://doi.org/10.5281/zenodo.161137.

[52] De Bono, E. (1999). Six Thinking Hats, Back Bay Books, New York.

[53] Aithal, P. S. \& Suresh Kumar, P. M. (2017). Lateral Thinking in Managerial Decision Making Through Six Thinking Hats Technique. International Journal of Scientific Research and Modern Education (IJSRME), 2 (1), 53-58. DOI: http://dx.doi.org/10.5281/ZENODO.4 38149.

[54] Aithal, P. S. \& Suresh Kumar, P. M. (2017). Ideal Analysis for Decision Making in Critical Situations through Six Thinking Hats Method. International Journal of Applied Engineering and Management Letters (IJAEML), 1(2), 1-9. DOI: http://dx.doi.org/10.5281/zenodo.838378.
[55] Aithal, P. S. \& Suresh Kumar P. M. (2017). Integrating Theory A and Six Thinking Hats for Improved Organizational Performance. International Journal of Applied Engineering and Management Letters (IJAEML), 1(2), 66-77. DOI: http://dx.doi.org/10.5281/zenodo.1045417.

[56] Shubhrajyotsna Aithal, \& Aithal, P. S., (2016), ABCD analysis of Dye doped Polymers for Photonic Applications. IRAInternational Journal of Applied Sciences, 4(3), 358-378. DOI: http://dx.doi.org/10.21013/jas.v4.n3.p1.

[57] Architha Aithal, and Aithal, P. S., (2017). ABCD Analysis of Task Shifting - An optimum Alternative Solution to Professional Healthcare Personnel Shortage. International Journal of Health Sciences and Pharmacy (IJHSP), 1(2), 3651.

DOI: http://dx.doi.org/10.5281/zenodo.1038975.

[58] Aithal, P. S., (2017). ABCD Analysis as Research Methodology in Company Case Studies. International Journal of Management, Technology, and Social Sciences (IJMTS), 2(2), 40-54. DOI: http://dx.doi.org/10.5281/zenodo.891621.

[59] Aithal, P. S. (2017). Factor Analysis based on ABCD Framework on Recently Announced New Research Indices. International Journal of Management, Technology, and Social Sciences (IJMTS), 1(1), 82-94. DOI: http://dx.doi.org/10.5281/zenodo.584105.

[60] Aithal, P. S. (2017). ABCD Analysis of Recently Announced New Research Indices. International Journal of Management, Technology, and Social Sciences (IJMTS), 2(1), 65-76. DOI: http://doi.org/10.5281/zenodo.583644.

[61] Aithal, P. S. \& Suresh Kumar, P. M. (2016). CCE Approach through ABCD Analysis of 'Theory A' on Organizational Performance. International Journal of Current Research and Modern Education (IJCRME), 1(2), 169-185. DOI: http://dx.doi.org/10.5281/ZENODO.164704 
[62] Aithal, P. S., Shailashree V. T. \& Suresh Kumar P.M. (2016). Factors \& Elemental Analysis of Six Thinking Hats Technique using ABCD Framework. International Journal of Advanced Trends in Engineering and Technology (IJATET), 1(1), 85-95. DOI

http://doi.org/10.5281/zenodo.240259.

[63] Varun Shenoy, \& Aithal P. S., (2016). ABCD Analysis of On-line Campus Placement Model, IRA-International Journal of Management \& Social Sciences, 5(2), 227-244. DOI: http://dx.doi.org/10.21013/jmss.v5.n2.p3.

[64] Varun Shenoy \& Aithal, P. S., (2017). Quantitative ABCD Analysis of IEDRA Model of Placement Determination. International Journal of Case Studies in Business, IT and Education (IJCSBE), 1(2), 103-113.

DOI: http://dx.doi.org/10.5281/zenodo.1133691.

[65] Aithal, P. S., and Shailashree, V. T., and Kumar, P. M. Suresh. (2016). ABCD Analysis of Stage Model in Higher Education. International Journal of Management, IT and Engineering, 6(1), 1124. DOI: http://doi.org/10.5 281/zenodo.154233.

[66] Aithal, P. S., Shailashree, V. T., \& Suresh Kumar, P. M. (2016). Analysis of NAAC Accreditation System using ABCD framework. International Journal of Management, IT and Engineering (IJMIE),
6(1), 30-44. DOI: http://doi.org/10. 5281/zenodo.154272.

[67] Aithal, P. S., Shailashree, V. T., \& Suresh Kumar, P. M. (2016). Application of ABCD Analysis Framework on Private University System in India. International Journal of Management Sciences and Business Research (IJMSBR), 5(4), 159$170 . \quad$ DOI http://doi.org/10.5281/zenodo.161111.

[68] Aithal, P. S., Shailashree, V. T., \& Suresh Kumar, P. M. (2016). The Study of New National Institutional Ranking System using ABCD Framework, International Journal of Current Research and Modern Education (IJCRME), 1(1), 389-402. DOI : http://doi.org/10.5281/zenodo.161077.

[69] Aithal, P. S., Shailashree, V. T. \& Suresh Kumar, P. M., (2016). Analysis of ABC Model of Annual Research Productivity using ABCD Framework. International Journal of Current Research and Modern Education (IJCRME), 1(1), 846-858. DOI : http://doi.org/10.5281/ zenodo.62022.

[70] Krishna Prasad \& Aithal P. S. (2018). ABCD Analysis of Fingerprint Hash Code, Password and OTP based Multifactor Authentication Model. Saudi Journal of Business and Management Studies, 3(1), 65-80. DOI: http://doi.org/10.21276/sjbms .2018.3.1.10. 